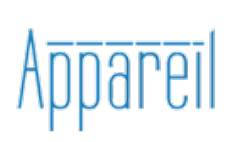

\title{
Appareil
}

4 | 2010

Biopolitique, éthique et subjectivation, questions de modernité

\section{Aesthetic realism and subjectivation. From Chris Marker to the Medvedkin Groups}

\section{Maria Muhle}

\section{(2) OpenEdition}

\section{Journals}

Electronic version

URL: https://journals.openedition.org/appareil/920

DOI: 10.4000/appareil.920

ISSN: 2101-0714

Publisher

MSH Paris Nord

Electronic reference

Maria Muhle, "Aesthetic realism and subjectivation. From Chris Marker to the Medvedkin Groups",

Appareil [Online], 4 | 2010, Online since 29 January 2010, connection on 12 October 2021. URL: http:// journals.openedition.org/appareil/920 ; DOI: https://doi.org/10.4000/appareil.920

This text was automatically generated on 12 October 2021.

\section{c) (†) $\odot$}

Appareil est mis à disposition selon les termes de la Licence Creative Commons Attribution - Pas d'Utilisation Commerciale - Pas de Modification 4.0 International. 


\title{
Aesthetic realism and subjectivation. From Chris Marker to the Medvedkin Groups
}

\author{
Maria Muhle
}

1 In a well-known discussion between Michel Foucault and Gilles Deleuze from 1972 on the relationship between intellectuals and power, Foucault states that the intellectual's traditional task has been to say the truth to those who haven't seen it yet and to say the truth in the name of those who are not able to say it. ${ }^{1}$ Consequently "conscience and eloquence" are the traditional characteristics of the politicized intellectual. Against this characterization, Foucault argues that a change has happened in "the latest resurgence":

[the] intellectuals realize that the masses can do without them and still be knowledgeable: the masses know perfectly well what's going on, it is perfectly clear to them, they even know better than the intellectuals do, and they say so convincingly enough. ${ }^{2}$

2 Yet this ability of the masses to develop political knowledge and discourse is confronted with a system of power that permeates the whole network of society and the aim of which is "to bar, prohibit, invalidate their discourse and their knowledge". ${ }^{3}$ The traditional figure of the intellectual is an element of this system of power. Consequently, Foucault concludes:

the role of the intellectual is no longer to situate himself "slightly ahead" or slightly "to one side" so that he may speak the silent truth of each and all; it is rather to struggle against those forms of power where he is both instrument and object in the order of "knowledge", "truth", "consciousness," and "discourse". Immediately after, Deleuze gives Foucault the credit of having been the first intellectual to take this "indignity of speaking for others" seriously:

What I mean is, we laughed at representation, saying it was over, but we didn't follow this 'theoretical' conversion through - namely, theory demanded that those involved finally have their say from a practical standpoint. ${ }^{5}$ 


\section{Prisons) and the specificity of the prise de parole of the prisoners:}

When the prisoners began to speak, they had their own theory of prison, punishment, and justice. What really matters is this kind of discourse against power, the counter-discourse expressed by prisoners [...], and not a discourse on criminality. ${ }^{6}$

In what follows I would like to examine more closely this "indignity of speaking for others". Deleuze's conclusion that "representation was over" has to be understood in a more nuanced manner, since it does not imply the end of representation as such, but the end of a specific hierarchy of representation: What is at stake is the suspension of the established relation between the represented reality or individuals and the images or words meant to represent them. This disrupting of the normative order of representation is twofold: it refers on the one hand to the end of the legitimacy of a critical discourse on a specific socially relevant situation, relying on the existence of a transcendent figure of an erudite or knowledgeable activist intellectual; and it highlights on the other hand a rupture with a specific hierarchical disposition of representation in the field of the aesthetics. The latter gives way to what I would like to call an "aesthetic realism": a representation beyond the traditional hierarchies of representation that define what can be said, in which register and by whom. This emancipation from the normative mimetic imperative entails a new politics of description that deposes the primacy of the narration of the great events over the description of the ordinary in its arbitrariness, and is thus inscribed in a biopolitical paradigm. Through the rupture with mimetic faithfulness, realist description becomes available to different forms of fictionalization and stylization, and breaks with the strict separation between the fictional and the documentary logic. It thus discovers an "aesthetic" or excessive power of signification in the things themselves, as well as the literarity of language as its an-archic potentiality of connecting the sensible (les sens) to signification (le sens), that blurs the univocal and harmonious distribution of places and spaces according to capacities and actions. What is at stake in aesthetic realism is thus the constitution of a political stage, i.e. a stage or space of appearance for bodies to be seen and discourses to be heard.

6 This construction of a new political stage is directly opposed to the assumption of a binary division between those who have knowledge and thus are aware of their conditions and those who have neither knowledge nor consciousness, and depend therefore on the transmission of knowledge and the unveiling of the ideological structures their life is trapped by. Following Foucault and Deleuze, but also Jacques Rancière, the political action can not aim at enlightening those who don't know or operate by occupying the speaker's position to represent them, but should instead aim at constructing a place of sensible appearance for those who traditionally, that is 'naturally', are not part of public life and thus of the construction of the common. This is what Rancière has characterised in terms of a distribution or redistribution of the sensible, i.e. of the common spatial and temporal conditions that enable or hinder the active partaking in the construction of this common. In Disagreement, Rancière refers to this gesture as a figure of subjectivation which he understands as a:

disidentification, a removal from the naturalness of a place, the opening up of a subject space where anyone can be counted since it is the space where those of no account are counted, where a connection is made between having a part and having no part. 
7 The opposite of subjectivation is thus identification, that is, the police activity of assigning every body its 'natural' place and function. To undermine the implementation of this 'natural' order, the subjectivation "repartitions the field of experience that gave to each other their identity with their lot". ${ }^{8}$ Politics is thought of in a theatrical sense as the historical aprioristic condition of the "perceptible organization" of the common - that is, as a space of appearance, a stage where a discourse and a visibility are possible - a stage that the police logic of inequality aims to prevent. Or, as Foucault puts it, what is to be changed is the political, economic, institutional regime of the production of truth, not the consciousness of the people, or whatever they might have in their head. ${ }^{9}$

8 Another way of accounting for this relationship between the figure of the "intellectual" and "the people" occurs in a series of films produced in 1967 and 1968 by Chris Marker and the Medvedkine Groups in Besançon and Solchaux. In March 1967, Pol Cèbe and other members of the Centre culturel populaire de Palente-les-Orchamps (CCPPO) invited the Parisian filmmaker Chris Marker to follow the strike and the occupation of the production plant of Rhodiacéta, a textile branch of Rhône-Poulenc in Besançon. In collaboration with Mario Marret and the workers of Rhodiacéta, Marker produced the film À bientôt, j'espère, which documents the ongoing social movements: The voice-over comments on the strike in February/March 67 at Rhodiacéta. It specifies the fact that it is the first occupation of a factory since 1936; it comments on its extended duration 26 days (Feb. 25 th - Mar. 24 $4^{\text {th }}$ 1967); and the fact that it spread quickly to other units of the firm. Despite providing this detailed background information, À bientôt j'espère presents this strike not as a singular event, but as part of a long list of social movements and strikes that, it claims, cannot be understood as an adding up of victories and defeats but as different "steps" within the same struggle. The film thus starts and ends with the documentation of another, less successful strike at the end of that same year. Besides these accounts, which are articulated through a rather traditional documentary style, the main interest of Marker and his film is to create a portrait of the small group of union activists, describing their lives by listening to them, by following their discussions and their political engagement as much as their family life.

9 The first scene is at once emblematic of the documentary style adopted by Marker and the film-ouvrier ("worker's film"), for which À bientôt j'espère is one of the first examples. We see one of the main actors of the social movement and of the film, Georges Maurivard, also known as Yoyo, union activist and worker at the Rhodiacéta, in front of the gates of the factory, trying to gather his co-workers to inform them about the dismissal of 92 workers in Lyon. It is a few days before Christmas, as the voice-over informs us, and thus months after the occupation and successful strike in February and March. The camera shows the workers leaving the factory (and gathering around the speaker) and so inevitably refers to the first scene ever shot in the history of cinema "The Workers leaving the factory" by the Lumière brothers, a 45 second-sequence depicting workers at the photography factory in Lyon owned by the brothers themselves, hurrying out of the factory gates. 
10 As Harun Farocki says in his documentary essay of the same title from 1995, this is the only moment when the workers become visible as a social group - the moment they leave the factory, when they are not yet dispersed into the private life outside the factory walls. Farocki follows this visibility throughout the history of cinema, from Charles Chaplin's Modern Times to Fritz Lang's Metropolis and Pier Paolo Pasolini's Accatone, and constructs the fictional image of this space in front of the factory gates as the place of social conflict par excellence, where private and public times and spaces collide and their difference fade, and where the possibility of resistance to the dominant order, that is, to the repartition and distribution of those times and spaces, unfolds..$^{10}$

11 Marker also chooses the factory gates as the starting point for his film, and relates this location to the very emergence of a "political culture". He does so by documenting the events, by interviewing the main characters of the social movement, by giving information about the factory and about the threat of massive dismissals that hover over the workers. The voice-over gives the necessary clues to understand the strike and by doing so inscribes the film in a classical documentary paradigm, where the documentary images reflect reality and the (authoritarian) voice-over explains this reality by situating it politically and historically. ${ }^{11}$ But this documentary dispositive that featuring, perhaps unintentionally, the figure of the filmmaker as author is disrupted throughout the movie by another tendency that abandons, in a figurative sense, the camera and the technical features to the workers themselves. In these moments, a discussion between the filmmaker, the technicians and the workers takes place, substituting the interview and blurring the boundaries between those that represent and the represented: the camera is no longer perceived as a technical medium that produces a binary separation, and has become instead an interlocutor. Also, the use of the voice-over as a necessarily "transcendent" dispositive is diverted from the classical setting at the moment when Marker's voice is replaced by the workers' and activists' own voices, commenting on and explaining the images. The whole film is thus inhabited by a specific oscillation between a classical use of documentary techniques and the admission of the need to break with the hierarchies inscribed in these techniques.

12 Nevertheless, À bientôt j'espère, when it was shown for the first time in the factory, was fiercely criticized by the workers themselves, who felt exploited and objectified by people that were supposed to fight this very exploitation. This critique, recorded as an audio document ironically entitled $L a$ Charnière, resulted in the formation of the Medvedkin Groups, who went on to make the film Classe de Lutte. In what follows I would like to explore the continuities but also the differences between Marker's film and the Medvedkin Groups' film. The central issue of both films is the theoretical and practical claim for a "right to culture", which has to be understood not as the access to mass information or entertainment but on the contrary as a political right. And it is a political right insofar its actualization implies a dissolution of the traditional distribution of the social occupations and places: It destabilizes the distribution of the hierarchies between the creative and the non-creative, between the active and the passive, and crystallizes in the appropriation by the workers of their own representation through a form of description that abandons explanation. It thus refers back to a right to leisure in the sense of free, non-reproductive time: The right to "waste time" and to be "un-determined" as Theodor W. Adorno puts it: "Rien faire 
comme une bête, auf dem Wasser liegen und friedlich in den Himmel schauen, 'sein, sonst nichts, ohne alle weitere Bestimmung und Erfüllung' [...]."12 exist in À bientôt j'espère: a) An interview in which Yoyo answers Marker's question about how he felt when, for the first time, he climbed onto a barrel and spoke out to the other workers. The interview follows the traditional exchange of questions and answers. b) Then Marker's voice occupies the stage and comments on the images of March 1967, highlighting the originality of the strike, and above all, "the idea, that [...] the imbalance in the working conditions translates into an imbalance in life in its totality, which could not be compensated by a salary increase". ${ }^{13}$ Correspondingly, the aim of the strike is not the integration into welfare society, but the questioning of this very form of social organisation. That explains why its tangible result is not first of all the increase in salaries, but the "education of a whole new generation of workers through social conflict". c) Then the voice-over switches back to Yoyo's voice, talking about the solidarity that springs up between the workers, the construction of a community, the integration of the workers in the support committees, in the functioning of the library... and poses the question of culture as a "political question". A banner shows the claims of the CСPPO: "bread for everybody, as well as freedom, laughter, theatre, life". d) In the following sequence Pol Cèbe states that the right to culture is a political claim exactly in the same manner as the right to bread or housing, even though the employers are not afraid to spell out the word culture whereas they are afraid to mention the word politics or the worker's union. ${ }^{14}$ What he leaves without saying, but is part of the subtext, is that the employers' disregard for culture constitutes a breach in the logic of domination, since culture, in this new definition proposed by the CCPPO, fundamentally relates to the distribution of places and roles in the common. By claiming the right to culture the worker claims the right to occupy a position that 'naturally' does not belong to him or her, the right to spend his time without working, with something that is not in any way connected to work or to the reproduction of his labour force - the right to "waste" his time.

The final sequence of À bientôt j'espère can be read as the summary of the oscillation that runs through the whole film between the will to produce knowledge and distribute information about the struggle of the working class in Besançon, and the will not to adopt a transcendent position in relation to the events. Following the Foucauldian approach, Marker tries to lead a "struggle side by side with those who are fighting and not off the side trying to enlighten them" ${ }^{15}$ But, still, there is a necessary imbalance between the filmmaker and those who are filmed that Marker cannot avoid: In the finishing statement Yoyo addresses both of these issues - the traditional political or even pragmatic problem of the access to the media as a form of mass communication, and their politics of misinformation regarding the working class; but also, and more importantly, the need for self-representation of the workers as part of the working class constituted through its struggle, its solidarity and its community. This selfrepresentation is not only articulated through the actual strikes, but also through a new politics of description, an auto-description of the workers and theoretical specific solidarity. This is what Yoyo defines, with a hesitating smile, as "culture": "Ce n'est pas de la culture ça?" This working class "culture" of solidarity and community, by 
definition unknown to the employers and factory owners, constitutes their power and will cause their victory in the social struggle against inequality and exploitation. What Yoyo announces here is the redefinition of the word culture in order to make it a militant word that belongs to the workers through which they auto-describe their struggle.

Classe de Lutte features this new culture, understood as the questioning of the 'naturalness' of things and their distribution. "Culture" refers to the excess of words and images that destabilizes the apparent 'natural' order of domination. In this sense the passing over of the technical support, i.e. of the camera, the cutting tables or the lighting from the hands of the militant filmmakers to the hands of the filmmaking workers is to be understood as a political gesture, as a gesture of militancy and of subjectivation in the Rancièrian sense, that is, as a gesture of disidentification: The camera follows a young woman, Suzanne Zedet, a worker in the Yéma watch-making factory who has already appeared in À bientôt j'espère, but only now has come to emancipate herself both as a militant activist and as a woman. While in 1967 her husband was literally speaking for her, she has now become an active participant within the social movements at Yéma. On the one hand, the collage of images mixes private and public scenes and spaces, factory and family life, suggesting the difficulty in separating the two realms. On the other, it is made out of images of the production and distribution of images: The technical support invades the framing and is exposed in the film, and thus refers, in a Brechtian way, to the artificiality of the actual situation. A banner on the wall of what seems to be the film studio underlines that film is not magic, that it is a technique in the service of the liberation of the workers. Following the figure of Suzanne the film shows the development of a militant culture understood as the self-description of the working class through the production of their counterdiscourses and their counter-images. This is strikingly summed up when Suzanne, working with her typewriter, is asked, presumably by her husband, what she is doing: She answers: "ben, je milite" - stating thus an evidence that has no need for explanations: that, in the life of an activist, every activity is political activity.

But this also has consequences for a reflection on the film as a medium, since it is no longer understood as a medium of representation (not even documentary representation), but as an instrument that promotes the fight of the workers - not by being a medium of communication but by rendering unstable the effective partitions and distributions. This argument is taken up again at the very end of the film in a less striking but not less effective manner: Suzanne, whose story the film has told us, abandons her identity as a militant worker, and instead gives detailed and erudite statements about Picasso and modern art, i.e. she disidentifies herself with her role as a worker and adopts the role of the art critic, which should "naturally" - i.e. in her natural role as a woman and a worker - not be accessible to her.

The film is thus neither a commentary on the workers' fights or their emancipation nor an explanation of its inner mechanisms or an exercise of contextualization. It doesn't follow an explanatory logic, but strings together self-reflecting images on the production of images and images that describe Suzanne's life as a militant working woman. But this new construction of Suzanne's identity is undermined both in form and content: Through the fictional dimension that is reflected throughout the movements of the camera, the images, the music and the presentation of Suzanne as the main character of her own story; and through Suzanne's disidentifying move, 
switching from the working woman to the militant worker and from there to the art critic. This way, the disidentifying gesture of the workers, who take the filming in their own hands, is reflected in the film itself. The production of an identity, that the film documents in a first step, is undermined precisely because Classe de Lutte - in opposition to À bientôt j'espère - does not represent a specific situation and its explanation; through the exposition of representation as representation and the possibility of redistributing spaces and times, Classe de Lutte points at a potentiality for a situation different to the current one.

Classe de Lutte arranges images, music and voices that speak for themselves and unfold their signification, without following an explanatory logic. The images do not "comment on" or "give reasons for" the emancipation of the working class; instead, their very existence is a movement of subjectivation understood as Suzanne's disidentification from the role of a working, speechless and thus both unrepresentable and inactive woman. In this sense, Classe de Lutte constitutes a new political stage, in which there is a collapse of the normative distribution of the roles and places within the sensible that determines that the workers work, the intellectuals think and the filmmakers make films. The film also avoids any transcendent voice, and thus participates in the new "culture or politics of self-description" that breaks both with the hierarchies of traditional narrative representation and the traditional position of the intellectual speaking for others. It is thus a form of aesthetic realism. Aesthetic realism understood as an immanent representation does not aim at being a "better" representation, but at the collapsing of the hierarchies of representation, and because of that it maintains the uncertainty of the distinction between documentary and fictional representation. The forms of aesthetic realism, as post-representative forms, do not show a reality "as it really is", but rather refer to the impossibility of doing so. However, this impossibility does not give way to the end of representation, but to a new politics of representation: an aesthetic politics of representation. The challenge of the notion of aesthetic realism is thus that it points to the impossible existence of an objective image and of an objective reality: Because reality and images are always negotiated and configured anew in the struggle between different strategies of distribution of roles and spaces or of different partitions of the sensible.

\section{BIBLIOGRAPHY}

Adorno Theodor W., «Sur l'eau », in Theodor W. Adorno, Minima Moralia. Reflexionen aus dem beschädigten Leben, Frankfurt am Main, Suhrkamp, 1969.

Foucault Michel, Deleuze Gilles, « Les Intellectuels et le pouvoir », in Michel Foucault, Dits et écrits I, Paris, Gallimard, 2001.

Foucault Michel, « La fonction politique de l'intellectuel », in Dits et écrits II, Paris, Gallimard, 2001. 
Foucault Michel, Deleuze Gilles, "Intellectuals and power", in Gilles Deleuze, Desert Islands and other texts, Los Angeles (Ca.)/London, Semiotext(e), 2004.

Nichols Bill, Representing Reality, Bloomington/Indianapolis, Indiana University Press, 1991.

Rancière Jacques, The Disagreement, Minneapolis, University of Minnesota Press 1998.

\section{NOTES}

1. Michel Foucault, Gilles Deleuze, "Les Intellectuels et le pouvoir », in Michel Foucault, Dits et écrits I, Paris, Gallimard, 2001, p. 1176 (not translated in the English version).

2. Michel Foucault, Gilles Deleuze, "Intellectuals and power", in Gilles Deleuze, Desert Islands and other texts, Los Angeles (Ca.)/London, Semiotext(e), 2004, p. 207.

3. Ibid.

4. Ibid.

5. Ibid.

6. Ibid.

7. Jacques Rancière, The Disagreement, Minneapolis, University of Minnesota Press 1998, p. 36.

8. Ibid., p. 40.

9. Michel Foucault, "La fonction politique de l'intellectuel", in Dits et écrits II, Paris, Gallimard, 2001, p. 114.

10. Harun Farocki: Arbeiter verlassen die Fabrik (D 1995).

11. Bill Nichols speaks in this context of a "Voice-of-God commentary", that characterizes the expository documentary. This moralizing trait will then disappear in the observational documentary that seems to adopt - thanks to mobile and unremarkable cameras and technical equipment - a neutral observer position. Both are opposed to the interactive and reflexive documentary whose aim is "to make the conventions of representation themselves more apparent and to challenge the impression of reality which the other three modes normally conveyed unproblematically". (Bill Nichols, Representing Reality, Bloomington/Indianapolis, Indiana University Press, 1991, p. 33.)

12. Theodor W. Adorno, "Sur l'eau ", in Theodor W. Adorno, Minima Moralia. Reflexionen aus dem beschädigten Leben, Frankfurt am Main, Suhrkamp, 1969, p. 208.

13. «L'idée continuellement reprise que le déséquilibre lié aux conditions de travail se traduit par un déséquilibre de toute la vie que nulle augmentation de salaire suffirait de compenser. »

14. «C'est à eux la culture, ils peuvent en causer, ils savent ce que c'est. »

15. Michel Foucault, Gilles Deleuze: “Intellectuals and power”, p. 207. 